\title{
Heavy Fuel Oil Recovery from Oil Sludge by Multiple Extraction Processes
}

\author{
Isam Al Zubaidi* \\ Faculty of Engineering and Applied Science, University of Regina, Canada \\ *Corresponding author : Isam Al Zubaidi, Faculty of Engineering and Applied Science, University of Regina, Canada.
}

Submission: 涀 March 19, 2018; Published: 眥 April 11, 2018

\begin{abstract}
Oil sludge from the bottom tank of shipping process was used to extract heavy fuel oil using multiple extraction techniques. Solvent extraction is necessary to recover valuable hydrocarbon from oil sludge and to reduce the volume of waste sludge so a further reduction in oil sludge has an impact effect on land and water. This process used methyl ethyl ketone (MEK) at different operating temperatures from room temperature to $50{ }^{\circ} \mathrm{C}$ and different solvent to sludge ratios. The percent recovery of heavy fuel oil was varied with these operating variables. The initial recovery was $43.46 \%$ at $50^{\circ} \mathrm{C}$ for the first extraction stage and increased to a total of $54.2 \%$ for the second extraction stage. The third extraction stage of the remaining solid was able to recover an additional quantity of oil to bring the total heavy fuel oil recovery to 62.2 mass $\%$ of the dry oil sludge. The physical properties of the recovered heavy fuel oil from each extraction stage were studied. The recovered heavy fuel oil from the third extraction stage showed higher specific gravity, carbon residue, ash content, and as phaltene content comparing with the first and second extraction stages.
\end{abstract}

Keywords: Oil sludge; Multiple extraction stages; Recovered heavy fuel oil

\section{Introduction}

The petroleum refining industry generates relatively large quantities of waste sludge from various sources including tank bottoms; slop oil emulsion solids and various sludges from oil/ water/solids separation. The accumulation of crude storage tank bottoms is a comparatively serious problem experienced by most refineries. The settling out of the sand, corrosion product and heavy fractions in the crude oil results in a loss of ullage in refinery crude storage tanks and causes refinery problems when introducing this sludge to the refinery processes. This may cause a fouling in the tubes of heat exchangers and solids/emulsions can pass from one area to another, which can result in downtime in production and frequent maintenance will require. Previously oil sludge had been disposed of at landfill sites and lagoons, valuable hydrocarbons have been sent offsite, which has both environmental and financial implications. Now, the disposal has become unacceptable, alternative solutions where oil recovery, re-use, and recycling can take place [1]. Solvent extraction can separate light hydrocarbons, which can be used as fuel. Petroleum refinery sludges typically comprise three phases and multiple components. They mainly consist of 20-90 wt\% water, 5-40 wt $\%$ oil, and about 5-35 wt $\%$ solids. It is shown that oily sludge is a water-in-oil emulsion, stabilized by fine solids [2]. The performance of several solvents to extract fuel oil from oily sludge was compared using many solvents [3]. MEK has the highest performance for fuel oil recovery. The amount of asphaltene in fuel oil was related to the concentration of fuel oil in the solvent phase during the extraction. This can be reached to the conclusion that asphaltene is extracted mainly by the fuel oil components, not the solvent [4]. The addition of commercial oil-water demulsifier increased the recovery of heavy fuel oil [5]. The effect of the addition of $\mathrm{KOH}$ to the solvent to enhance the recovery process of fuel oil from oil sludge was investigated [6].

\section{Materials and Methods}

Oil sludge was homogenized using overhead stirrer for about one hour; free water was removed and dry oil sludge was stored in the refrigerator. The properties of the oil sludge are shown in Table 1. Methyl ethyl ketone (MEK) with 99\% purity was taken as a solvent. Samples of oil sludge were added to MEK with mass ratios of solvent-to-sludge of 4:1 was used. Different operating temperatures ranging room temperature to $50^{\circ} \mathrm{C}$ were studied. The sludge-solvent mixture was stirred using rocker type incubator for two hours. The sludge-solvent mixture was gravity-filtered; the semi-solid material was dried in a furnace at $80{ }^{\circ} \mathrm{C}$ to remove any solvent. The extract was distilled using simple distillation apparatus. The solvent was recovered as distillate until the flow of distillate dramatically decreased. The distillation temperature was around $80{ }^{\circ} \mathrm{C}$ for MEK. The amount of solvent recovered through distillation was taken and compared with the amount originally added prior the mixing step. The amount of solvent recovered varied from $87 \%$ to $93 \%$ of the original amount. The collected data for the amount of oil sludge, solvent, recovered oil, recovered 
solvent, and the remaining solid are shown in Table 2. The wet solid material was subjected to further extraction steps at the same extraction temperature to separate heavier fuel oil associated with this solid.

Table 1: Properties of the oil sludge. All percentages are by mass.

\begin{tabular}{|c|c|}
\hline Property & Value \\
\hline Water content, mass $\%$ & $4.10 \%$ \\
\hline
\end{tabular}

\begin{tabular}{|c|c|}
\hline $\begin{array}{c}\text { Sediment and Ash, dry basis, } \\
\text { mass } \%\end{array}$ & $8.20 \%$ \\
\hline Carbon residue, mass $\%$ & $9.50 \%$ \\
\hline $\begin{array}{c}\text { Asphaltene content as heptane } \\
\text { insoluble, mass } \%\end{array}$ & $10.40 \%$ \\
\hline Organic material, dry basis, mass $\%$ & $91.20 \%$ \\
\hline Specific gravity@ $15^{\circ} \mathrm{C}$ & 0.905 \\
\hline
\end{tabular}

Table 2: mass of sludge, solvent, oil recovered, and remaining solids using MEK solvent with 4: 1 mass ratios of solvent to oil sludge.

\begin{tabular}{|c|c|c|c|c|c|c|c|}
\hline & Temperature ${ }^{\circ} \mathbf{C}$ & Oil Sludge g & $\mathbf{~}$ & $\begin{array}{c}\text { Recovered } \\
\text { Solvent }\end{array}$ & \% Fuel Oil & $\begin{array}{c}\text { \% Solvent } \\
\text { Recovered }\end{array}$ & $\begin{array}{c}\text { Solid } \\
\text { Remaining g }\end{array}$ \\
\hline 22 & 40.65 & 16.56 & 135.4 & 40.73 & 84.63 & 23.21 & 2.16 \\
\hline 30 & 40.6 & 16.95 & 140.38 & 41.747 & 87.7 & 22.49 & 2.86 \\
\hline 35 & 40.3 & 17.13 & 139.3 & 42.5 & 87.1 & 22.48 & 1.71 \\
\hline 40 & 40.4 & 17.55 & 137.75 & 43.448 & 86.1 & 20.69 & 5.3 \\
\hline 45 & 40.7 & 17.68 & 136.6 & 43.446 & 85.4 & 22.97 & 0.12 \\
\hline 50 & 40.1 & 17.43 & 140.35 & 43.46 & 87.7 & 22.5 & 0.43 \\
\hline
\end{tabular}

\section{Results and Discussion}

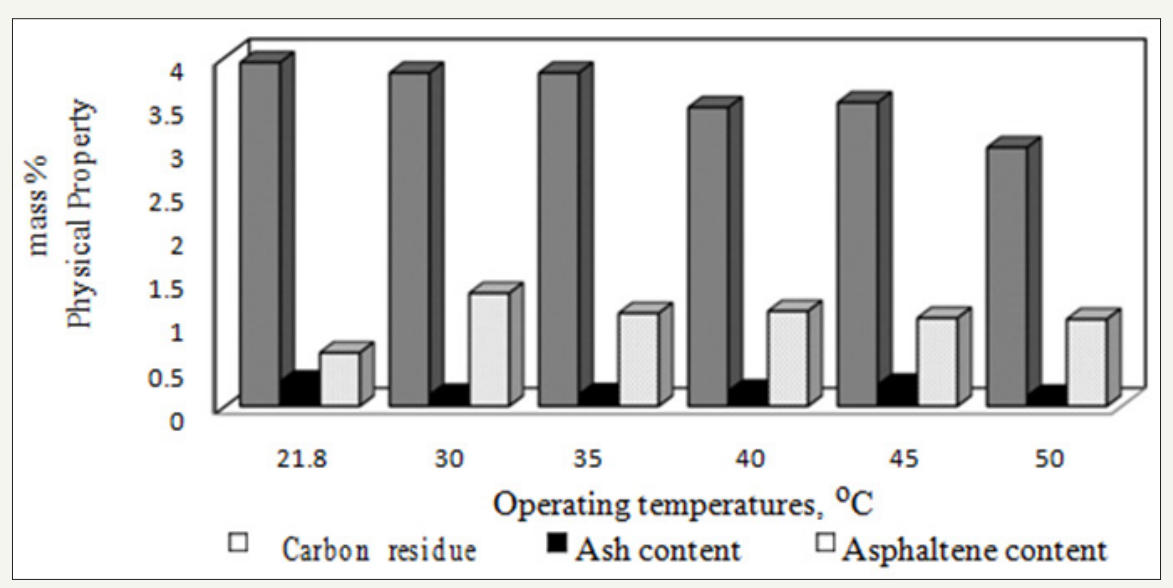

Figure 1: Physical properties of recovered fuel oil with operating temperature.

Table 3: Properties of the recovered oil at $50 \mathrm{C}$ using MEK as a solvent with commercial fuel oil recovered from oil sludge.

\begin{tabular}{|c|c|c|}
\hline Property & Recovered Oil & $\begin{array}{c}\text { Recovered Oil } \\
\text { from Environment } \\
\text { Company }\end{array}$ \\
\hline $\begin{array}{c}\text { Specific gravity @ } \\
15^{\circ} \mathrm{C}\end{array}$ & 0.885 & 0.892 \\
\hline Carbon residue & $2.97 \%$ & $3.32 \%$ \\
\hline Ash content & $0.12 \%$ & 0.702 \\
\hline Asphaltene content & $1.00 \%$ & 3.94 \\
\hline Water content, vol.\% & $\mathrm{Nil}$ & $6.40 \%$ \\
\hline Sulfur content & 2.22 & 0.543 \\
\hline Salt content, $\mathrm{mg} / \mathrm{kg}$ & 12 & 196.4 \\
\hline Flash point & $56 \mathrm{C}$ & 70 \\
\hline
\end{tabular}

\begin{tabular}{|c|c|c|}
\hline Viscosity, cst, @ $40^{\circ} \mathrm{C}$ & 104.4 & 88.8 \\
\hline $\begin{array}{c}\text { Heat of combustion, } \\
\mathrm{kJ} / \mathrm{Kg}\end{array}$ & 44,500 & 42,584 \\
\hline
\end{tabular}

The recovered oil was analyzed to determine the ash content, Conradsorn carbon residue, and asphaltene content as heptane insoluble. These results are provided in Figure 1 for different operating temperatures.

The values of carbon residue, ash content is ranging from 0.117 to 0.283 mass $\%$ and the best quality oil recovered is at $50{ }^{\circ} \mathrm{C}$. The asphaltene content as heptanes insoluble is ranging from 0.613 to 1,295 mass $\%$ and the second best value was at $50^{\circ} \mathrm{C}$. The extraction process of oil sludge at $50{ }^{\circ} \mathrm{C}$ had the highest oil recovery and almost the best oil quality although the higher recovery of oil means extracting of more heavier oils with high viscosities which are not easy to separate at low temperatures but the specific gravity of the 
recovered oil showed approximate same values for all recovered oil from different operating temperatures. The recovered oil was compared with the recovered oil from a commercial environmental service company. The analysis of the recovered oil from this work is still better than the commercial plant recovery oil. This extraction work shows lower values in carbon residue, ash content, asphaltene content, water content, salt content, and metals content (Table 3 \&
4). These tables show higher values in sulphur content, viscosity, and heat of combustion and a reduction in the metal content of iron, copper, nickel, vanadium, calcium, magnesium, phosphorous, zinc, aluminum, barium, lead, and silicone. It is believed that all these metals are concentrated in the remaining solids and the iron metal was coming from the corrosion process of the storage tank.

Table 4: Metal content of recovered oil compared with commercial plant and commercial fuel oil.

\begin{tabular}{|c|c|c|}
\hline Metal & Metals in Recovered Oil at $50^{\circ} \mathrm{C}(\mathrm{mg} / \mathrm{kg})$ & $\begin{array}{c}\text { Metals in Recovered Oil from Environment } \\
\text { Company }(\mathrm{mg} / \mathrm{kg})\end{array}$ \\
\hline Iron $(\mathrm{Fe})$ & 126 & 163 \\
\hline Copper (Cu) & 3 & 4 \\
\hline Nickel (Ni) & 5 & 8 \\
\hline Vanadium (V) & 16 & 24 \\
\hline Manganese (Mn) & $<1$ & 1 \\
\hline Boron (B) & 4 & 4 \\
\hline Sodium (Na) & 236 & 56 \\
\hline Calcium (Ca) & 20 & 1117 \\
\hline Magnesium (Mg) & 3 & 20 \\
\hline Phosphorus (P) & 30 & 146 \\
\hline Zinc (Zn) & 6 & 168 \\
\hline Aluminum (Al) & $<1$ & 15 \\
\hline Barium (Ba) & 2 & 10 \\
\hline Lead $(\mathrm{Pb})$ & $<1$ & 2 \\
\hline Molybdenum (Mo) & $<1$ & $<1$ \\
\hline Silicon (Si) & 5 & 22 \\
\hline Silver (Ag) & 2 & 1 \\
\hline Cadmium (Cd) & $<1$ & $<1$ \\
\hline Chromium (Cr) & $<1$ & 1 \\
\hline $\operatorname{Tin}(\mathrm{Sn})$ & $<1$ & $<1$ \\
\hline Titanium (Ti) & $<1$ & 1 \\
\hline
\end{tabular}

\section{Multiple Extraction Processes}

Multiple extraction processes for wet solid remaining using 4: 1 MEK to solid masses at operating temperature of $50{ }^{\circ} \mathrm{C}$. The mass of wet solid remaining, MEK, oil recovered, solvent recovered, and the remaining solid are shown in Table 5. The mass percent of the fuel oil recovery from multiple extraction processes from oil sludge and remaining solid can be represented in Figure 2. The accumulated amount of recovered heavy fuel oil in three extraction steps was equal to $62.2 \%$ of the total mass of the dry oil sludge. The main physical properties of the recovered oil from the dual and triple extraction process are shown in Figure 3. This represents $95 \%$ of the total amount of the oil in the oil sludge. This means that the quality of the recovered heavy fuel oil is better for the first extraction step compared with the other steps.

Table 5: Oil recovered and solid remaining using 4:1 MEK at operating temperature of $50 \mathrm{oC}$.

\begin{tabular}{|c|c|c|c|c|c|c|c|c|}
\hline \multirow{2}{*}{ Extraction } & \multirow{2}{*}{ Wet Solid, g } & \multirow{2}{*}{$\begin{array}{c}\text { Mass of } \\
\text { Solvent, } \mathrm{g}\end{array}$} & \multicolumn{2}{|c|}{ Oil Recovered } & \multicolumn{2}{|c|}{ Solid Remaining } & \multicolumn{2}{|c|}{ Solvent Recovered } \\
\hline & & & Mass g & $\%$ & Mass & $\%$ & Mass & $\%$ \\
\hline 2nd Ext. & 40.34 & 161.36 & 4.326 & 10.723 & 34.44 & 85.37 & 150.24 & 93.11 \\
\hline Third Ext. & 17.8 & 71.2 & 1.426 & 8.012 & 15.5 & 87.1 & 65.4 & 91.9 \\
\hline
\end{tabular}




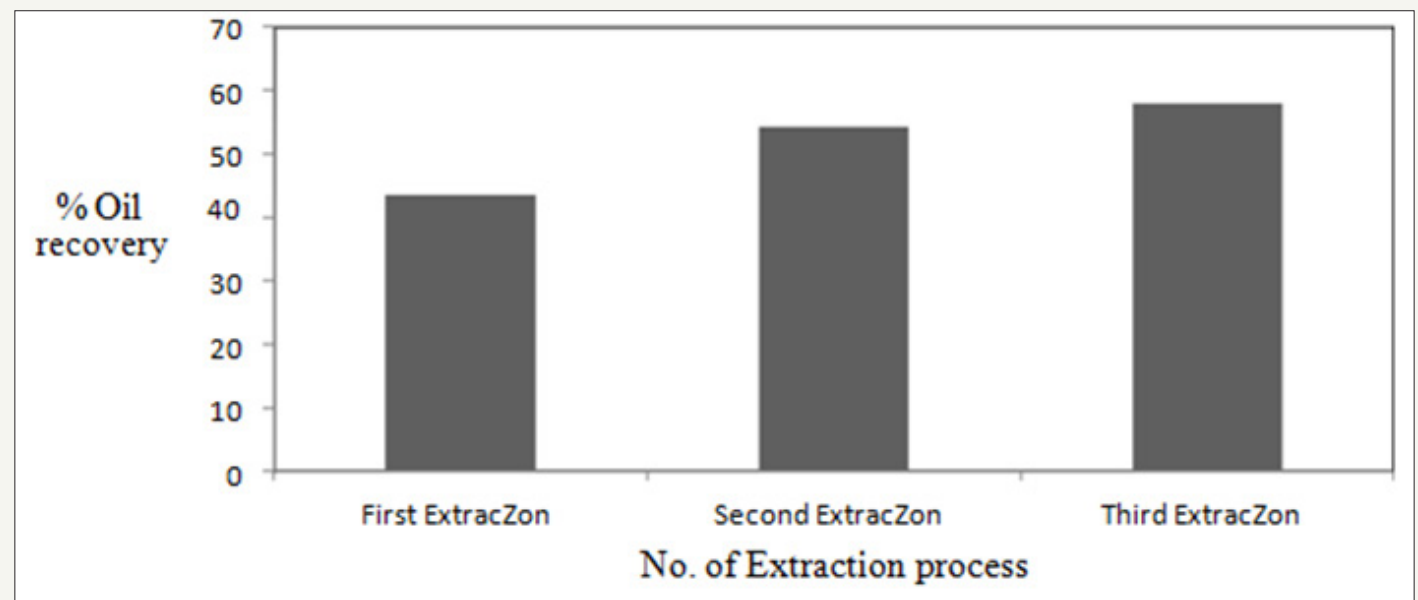

Figure 2: \% Oil recovery with number of extraction process.

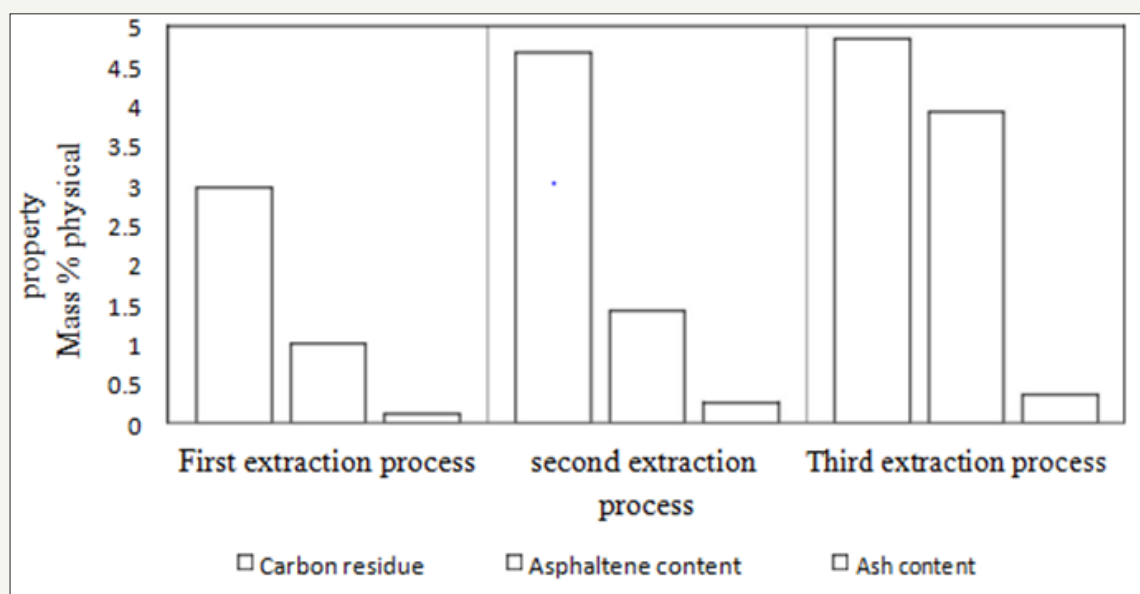

Figure 3: Physical properties of extracted oil for the first, second and third extraction process.

\section{Conclusion}

Solvent extraction of oil sludge using MEK was studied at different operating temperatures to recover a valuable heavy fuel oil. The heavy fuel oil was recovered from oil sludge in three extraction steps at $50{ }^{\circ} \mathrm{C}$. The temperature plays an important factor in the fuel oil recovery from oil sludge. Multiple extraction processes were used to recover more fuel oil although the quality of the fuel oil is not good. It is required to optimize the number of extraction steps with the quality of fuel oil in any recovery process. This work was able to recover $62.2 \%$ of the dry oil sludge and $95 \%$ of the oil present in the oil sludge using three steps extraction process. More treatment is required for the remaining solid before it landfills.

\section{References}

1. Kam EKT (2001) Assessment of sludge and tank bottoms treatment processes. $8^{\text {th }}$ International Petroleum Environmental Conference. Houston, USA.

2. Elektorowicz M, Habibi S, Chifrina R (2006) Effect of electrical potential on the electro-demulsification of oily sludge. J Colloid Interface Sci 295(2): 535-541.

3. Abouelnasr DM, Zubaidi I (2008) Treatment and recovery of oil-based sludge using solvent extraction. In Proceedings of the Abu Dhabi International Petroleum Exhibition \& Conference, UAE.

4. Isam AH Zubaidi, Dana M Abouelnasr (2010) Fuel recovery from waste oily sludge using solvent extraction. Process Safety and Environmental Protection 88(5): 318-326.

5. Abouelnasr Dana M, Al Zubaidi Isam AH (2009) Fuel Recovery from Waste Oil Sludge Using Solvent Extraction Combined with a Demulsifier. Proceedings of the Fourth International Exergy, Energy and Environment Symposium. Sharjah, UAE.

6. Zubaidi I Al (2016) Effect of additives on fuel recovery from oil sludge using solvent extraction technique, World Heavy Oil Congress, Calgary, Canada. 
Creative Commons Attribution 4.0 International License

For possible submissions Click Here

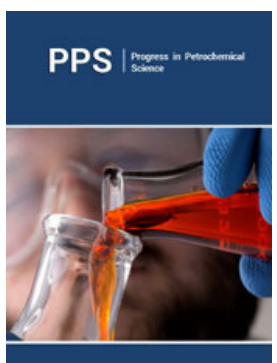

\section{Progress in Petrochemical Science}

\section{Benefits of Publishing with us}

- High-level peer review and editorial services

- Freely accessible online immediately upon publication

- Authors retain the copyright to their work

- Licensing it under a Creative Commons license

- Visibility through different online platforms 